\title{
Pengaruh Pemberian Pupuk Kalium terhadap Kualitas Dua Varietas Ubi Jalar (Ipomoea batatas L.)
}

\section{(The Effect of Potassium Fertilizer on the Quality of Two Varieties of Sweet Potatoes (Ipomoea batatas L.))}

\author{
Marchel Putra Garfansa ${ }^{1 \bullet}$, Sudiarso ${ }^{2}$, Nur Edy Suminarti ${ }^{2}$ \\ ${ }^{1}$ Fakultas Pertanian, Universitas Islam Madura, Pamekasan \\ ${ }^{2}$ Fakultas Pertanian, Universitas Brawijaya, Malang \\ `Email korespondensi: marchel.sp.mp@gmail.com
}

\begin{abstract}
Indonesia, which is a tropical country, sweet potatoes can be grown on almost all islands in Indonesia. Sweet potatoes come in many varieties. Sweet potato plants are known to be very responsive to potassium. It is hoped that this research obtains information about the correct proportion of potassium fertilizer in each tested variety so that the productivity of the sweet potato plant can be increased. The experiment using the Split Plot Design was repeated three times. The main plot is Varieties (V), such as Gunung Kawi Variety and Cilembu Variety. The sub-plot is the $\mathrm{KCl}$ dose $(\mathrm{K})$ which consists of 5 types such as, $K 0=0 \mathrm{~kg} \mathrm{ha}^{-1}, \mathrm{Kl}=78 \mathrm{~kg} \mathrm{ha}{ }^{-1}, \mathrm{~K}^{2}$ $=137 \mathrm{~kg} \mathrm{ha}^{-1}, \mathrm{K3}=196 \mathrm{~kg} \mathrm{ha}^{-1}$ and $\mathrm{K} 4=225 \mathrm{~kg} \mathrm{ha}^{-1}$. The results of the observations were analyzed using the variance test ( $F$ test) at the $5 \%$ and $1 \%$ levels. If there is a significant difference, it will be followed by the HSD test at the $5 \%$ level with correlation and regression tests. The results showed that the application of potassium fertilizer affects the quality of the sweet potato plants of both varieties. Giving potassium $225 \mathrm{~kg} \mathrm{ha}^{-1}$ was able to increase fiber content by $35 \%$ but had an impact on reducing chlorophyll content by $14 \%$.
\end{abstract}

Keywords: potassium; quality; fertilizer; sweet potatoes; varieties

Abstrak. Indonesia, yang merupakan negara tropis, ubi jalar dapat tumbuh di hampir semua pulau di Indonesia. Ubi jalar memiliki berbagai varietas. Tanaman ubi jalar dikenal sangat responsif terhadap potasium. Diharapkan melalui penelitian ini akan diperoleh informasi tentang proporsi pupuk kalium yang tepat dalam setiap varietas yang diuji sehingga produktivitas tanaman ubi jalar dapat ditingkatkan. Eksperimen menggunakan Split Plot Design diulang tiga kali. Petak utama adalah Varietas (V), seperti Variasi Gunung Kawi dan Varietas Cilembu. Sub plot adalah Dosis $\mathrm{KCl}(\mathrm{K})$ yang terdiri dari 5 jenis seperti, $\mathrm{K} 0=0 \mathrm{~kg} \mathrm{ha}^{-1}, \mathrm{~K} 1=78 \mathrm{~kg} \mathrm{ha}^{-1}, \mathrm{~K} 2=137 \mathrm{~kg} \mathrm{ha}^{-}$ ${ }^{1}, \mathrm{~K} 3=196 \mathrm{~kg} \mathrm{ha}^{-1}$ dan $\mathrm{K} 4=225 \mathrm{~kg} \mathrm{ha}^{-1}$. Hasil observasi dianalisis dengan uji varians (uji F) pada level $5 \%$ dan $1 \%$. Jika ada perbedaan yang signifikan, akan dilanjutkan dengan uji BNJ pada level 5\% dengan korelasi dan uji regresi. Hasil penelitian menunjukkan, bahwa pemberian pupuk kalium dapat mempengaruhi kualitas dari tanaman ubi jalar kedua varietas. Pemberian kalium $225 \mathrm{~kg}$ ha-1 mampu meningkatkan kadar serat umbi sebesar $35 \%$ namun berdampak pada pengurangan kandungan klorofil sebesar $14 \%$.

Kata kunci: kalium; kualitas; pupuk; ubi jalar; varietas

\section{PENDAHULUAN}

Tanaman ubi jalar adalah salah satu tanaman yang mudah dibudidayakan oleh petani. Di Indonesia, yang merupakan negara tropis, ubi jalar dapat ditanam di hampir semua pulau di Indonesia. Ubi jalar diketahui mengandung karbohidrat, vitamin, dan mineral sehingga memiliki nilai ekonomi tinggi. Selain digunakan sebagai makanan alternatif, ubi jalar juga bisa diolah menjadi berbagai bentuk olahan seperti tepung dan bahan kosmetik, sedangkan limbahnya bisa digunakan untuk pakan ternak. Inilah yang menyebabkan tanaman ubi jalar menjadi salah satu komoditas penting di Indonesia (Jusuf \& Ginting, 2014).

Pesatnya perkembangan tanaman ubi jalar tidak hanya ditunjukkan pada produk olahan yang dihasilkan namun diciptakannya berbagai macam varietas ubi jalar yang dapat unggul dalam segi tampilan dan kandungannya. Seleksi dan pemilihan varietas perlu dilakukan untuk mendapatkan potensi yang diinginkan petani (Trustinah \& Iswanto, 2013). Peningkatan kualitas yang lebih baik juga akan berdampak pada meningkatnya minat konsumen akan ubi jalar. Interaksi genotip dengan lingkungan memiliki pengaruh yang signifikan terhadap komponen kualitas ubijalar. Sehubungan 
dengan masalah ini, perlu untuk mengelola kondisi tanah melalui pemupukan.

Pupuk kalium dikenal memiliki peran dalam meningkatkan kualitas dan kuantitas tanaman ubi jalar karena fungsinya yang mempengaruhi pembentukan umbi. Kalium adalah unsur yang dibutuhkan untuk tanaman penghasil karbohidrat, terutama tanaman ubi jalar. Pupuk kalium merupakan satu dari enam belas unsur hara esensial yang dibutuhkan tanaman untuk tumbuh dan berkembang. Tersedianya unsur kalium yang rendah akan menyebabkan terjadinya gejala defisiensi unsur hara. Kalium memiliki fungsi sebagai metabolism karbohidrat serta berperan dalam peningkatan daya tahan tanaman terhadap penyakit serta kualitas umbi yang dihasilkan (Pushpalatha et al., 2017; Simo et al., 2017). Pada tanaman kentang yang kekurangan kalium daun akan berubah warna kecoklatan yang diikuti nekrosis pada bagian tepi daun. Di sisi lain, dampak jumlah $\mathrm{K}$ yang tinggi yang terkandung di dalam tanah justru akan menghambat pertumbuhan tanaman. Tanaman yang memiliki kelebihan $\mathrm{K}$ akan menyebabkan munculnya bintik-bintik kuning pada permukaan daun persis seperti gejala etiolasi atau kurangnya cahaya pada tanaman menyebabkan fotosintesis menjadi terganggu, jumlah asimilasi yang dihasilkan menurun, dan akan mempengaruhi hasil produktivitas tanaman.

Ubi jalar merupakan tanaman tropis yang dapat tumbuh baik di sub tropis. Ubi jalar umumnya dibagi menjadi dua jenis umbi yaitu ubi jalar berumbi lunak (mengandung air lebih banyak) dan ubi jalar berumbi keras (kaya akan serat). Genotip pada ubi jalar dipengaruhi oleh lingkungan. Respon genotip yang berbeda akibat adanya pengaruh interaksi genotip dengan lingkungannya (Anggraini \& Sri, 2019). Faktor yang mempengaruhi tersebut salah satunya adalah pupuk Kalium. Ketersediaan pupuk kalium dapat mempengaruhi kualitas umbi seperti kandungan serat dan kadar gula yang dihasilkan. Hal tersebut didukung oleh penelitian Pusphalata. et al, (2017: 16891696) yang menjelaskan dengan penambahan kalium $100 \mathrm{~kg} \mathrm{ha}^{-1}$ mampu meningkatkan kadar gula ubi jalar sebesar $17 \%$ dibandingkan perlakuan tanpa pupuk kalium. Ubi jalar memiliki berbagai macam varietas antara lain Papua Salossa, Sawentar, Sari, Jago, Cilembu dan Gunung Kawi (Saitama et al., 2017). Varietas cilembu dan Gunung kawi adalah yang banyak diminati oleh konsumen karena rasa yang manis serta mudah untuk dibudidayakan.

Varietas Cilembu banyak digemari dikalangan masyarakat karena rasa manis dan nutrisinya yang tinggi. Rata-rata kadar gula pada umbi Cilembu berkisar $5.39 \%$ $6.97 \%$ dalam keadaan mentah, sementara kandungan gula pada umbi ubi jalar biasa hanya sekitar $2.38 \%$ menyebabkan umbi Cilembu memiliki rasa manis yang tinggi. Di sisi lain terdapat varietas Gunung Kawi dimana tingkat kemanisannya hampir menyerupai umbi yang dihasilkan oleh varietas Cilembu. Varietas Gunung Kawi memiliki kandungan karbohidrat dan pigmen antosianin yang tinggi. Selain itu varietas Gunung Kawi memiliki jumlah hasil umbi yang lebih banyak dibandingkan varietas ubi jalar lainnya menyebabkan varietas Gunung Kawi digemari oleh petani (Suhardi et al., 2016).

Mengingat pentingnya manfaat dari nutrisi ini, penelitian ubi jalar perlu diarahkan untuk meningkatkan kualitas ubi jalar itu sendiri. Pemberian unsur kalium bertujuan untuk menjaga tingkat kemanisan umbi tetapi aplikasi berlebihan akan benarbenar menyebabkan tanaman ubi jalar mengalami keracunan dan berdampak pada pertumbuhan tanaman. Sehubungan dengan masalah ini, perlu untuk meneliti tingkat pupuk K yang sesuai.

\section{METODE PENELITIAN}

Penelitian ini dilakukan di Desa Dadaprejo, Kecamatan Semanding, Malang, Jawa Timur pada dataran menengah dengan 
ketinggian 520 meter di atas permukaan laut (mdpl) dan suhu antara $27^{\circ} \mathrm{C}-29^{\circ} \mathrm{C}$. Tekstur tanah: lempung berdebu, $\mathrm{N}$-total: 0,14\%, P-tersedia: 28,6 ppm, K-tersedia: $0,14 \mathrm{ppm}$. Desain penelitian, pengobatan dan pengumpulan data Percobaan faktorial diatur dalam desain petak terpisah dan diulang tiga kali. Petak utama adalah Varietas (V), sedangkan sub plot adalah jarak tanam. Petak utama terdiri dari 2 varietas, V1 = Gunung Kawi Variety dan V2 $=$ Cilembu Variety. Sub plot adalah Dosis $\mathrm{KCl}(\mathrm{K})$ yang terdiri dari 5 jenis seperti, $\mathrm{K} 0$ $=0 \mathrm{~kg} \mathrm{ha}^{-1}$ (kontrol), $\mathrm{K} 1=78 \mathrm{~kg} \mathrm{ha}^{-1}, \mathrm{~K} 2=$ $137 \mathrm{~kg} \mathrm{ha}^{-1}, \mathrm{~K} 3=196 \mathrm{~kg} \mathrm{ha}^{-1}$ dan K4 = 225 $\mathrm{kg} \mathrm{ha}^{-1}$. Percobaan direplikasi 10 plot dan diulang sebanyak 3 kali, jadi ada 30 unit plot percobaan. Tahapan penelitian dimulai dari perbanyakan, persiapan lahan, penanaman, pemeliharaan dan panen. Area plot adalah 3 x $3,2 \mathrm{~m}$, jarak antara perawatan adalah $100 \mathrm{~cm}$ dan antara ulangan adalah $50 \mathrm{~cm}$. Luas total eksperimen adalah 15,2 mx 37,5 m. Pengamatan dilakukan secara destruktif dengan mengambil dua tanaman sebagai sampel pada 20, 40, 60 dan 80 hari setelah tanam dari parameter yang diamati pada setiap pengamatan, sedangkan umbi segar dilakukan pada umur tanaman 120 hari setelah tanam.

Pengamatan kandungan klorofil, kadar serat, dan kadar Gula. Kandungan klorofil diukur menggunakan Spektofotometer UVVIS. Pengukuran kadar Kadar Gula menggunakan metode Nelson Somogy. Analisis data menggunakan analisis varians dengan uji $\mathrm{F}$ 5\% untuk menunjukkan apakah data memiliki interaksi yang signifikan atau tidak ada perbedaan yang signifikan pada perlakuan. Jika hasil $F$ hitung $>F$ tabel berarti data berbeda secara signifikan dan dilanjutkan dengan uji BNJ (Beda Nyata Jujur) pada level 5\%.

\section{HASIL DAN PEMBAHASAN}

\section{Kandungan Klorofil}

Ubi jalar yang diberi perlakuan $\mathrm{KCl}$ $130 \%$ menunjukkan hasil yang tidak berbeda nyata jika dibandingkan perlakuan $70 \%$ dan $100 \%$. Walaupun demikian untuk perlakuan $130 \%$ menunjukkan kandungan klorofil yang nyata lebih rendah dibandingkan perlakuan $40 \%$ dan kontrol (Tabel 1). Peningkatan pemberian pupuk $\mathrm{KCl}$ diikuti dengan penurunan pada kandungan klorofil. Pada peningkatan dosis $\mathrm{KCl}$ dari kontrol hingga $130 \%$ terjadi penurunan total klorofil daun sebesar $14 \%$ walaupun demikian untuk perlakuan $40 \%$, $70 \%$ dan $100 \%$ menunjukkan total klorofil yang tidak berbeda nyata jika dibandingkan dengan perlakuan kontrol. Hal tersebut dikarenakan adanya kenaikan unsur $\mathrm{K}$ dalam tanah yang kemudian diserap tanaman dalam jumlah banyak. Unsur $\mathrm{K}$ dikenal sebagai unsur yang bersifat antagonis bagi unsur magnesium (Mg). (Y. Ding et al., 2006) menjelaskan bahwa penambahan unsur $\mathrm{K}$ yang berlebih pada tanaman akan menimbulkan efek antagonis antara unsur $\mathrm{K}$ dan $\mathrm{Mg}$ sehingga ketersediaan $\mathrm{Mg}$ menjadi rendah. Ketika kandungan unsur $\mathrm{K}$ dalam tanah berlebih, kemungkinan beberapa unsur $\mathrm{Mg} 2+$ dan $\mathrm{Ca} 2+$ akan tertahan dan digantikan oleh ion $\mathrm{K}+$ menyebabkan terlarutnya unsur $\mathrm{Mg}$ dan $\mathrm{Ca}$ (Bolan et al., 2005). Unsur magnesium memiliki pengaruh yang penting dalam ketersediaan klorofil pada daun.

Magnesium berperan dalam pembentukan zat hijau daun (klorofil) dan membantu proses metabolisme tanaman seperti proses fotosintesis, pembentukan sel, pembentukan protein, dan pembentukan pati. $\mathrm{Mg}$ merupakan satu-satunya ion metal yang terkandung dalam klorofil sehingga kekurangan $\mathrm{Mg}$ dapat menurunkan kandungan klorofil pada daun yang mana akan berdampak pada proses fotosintesis tanaman. Pada penelitian Ding et al. (2008) memperlihatkan bahwa rendahnya unsur $\mathrm{Mg}$ akan berdampak pada menurunnya kandungan klorofil dan aktivitas fotosintesis. Pernyataan tersebut juga 
didukung pada parameter klorofil yang mana pada tanaman yang diberi perlakuan kontrol maupun yang di pupuk $\mathrm{KCl}$ dosis $40 \%$, nilai klorofil yang dihasilkan nyata lebih tinggi dibandingkan dengan $100 \%$ dan $130 \%$. Hal ini terkait dengan peran klorofil dalam menghasilkan asimilat yang diketahui sebagai energi pertumbuhan dan perkembangan tanaman. Klorofil merupakan kunci penting dalam fotosintesis, sehingga dengan meningkatnya klorofil akan meningkatkan aktivitas fotosintesis yang berpengaruh pada hasil dan tumbuh kembang tanaman (Subaedah et al., 2016).

Tabel 1. Rerata kandungan klorofil daun ubi jalar pada berbagai dosis pemupukan $\mathrm{KCl}$ Saat panen

\begin{tabular}{lc}
\hline \multicolumn{1}{c}{ Dosis Pupuk KCl } & Total Klorofil Daun $\left(\mu \mathrm{m}\right.$ berat segar $\left.{ }^{-1}\right)$ \\
\hline $\mathrm{K}_{0}\left(0 \mathrm{~kg} \mathrm{ha}^{-1}\right)$ & $1070 \mathrm{~b}$ \\
$\mathrm{~K}_{1}\left(78 \mathrm{~kg} \mathrm{ha}^{-1}\right)$ & $1060 \mathrm{~b}$ \\
$\mathrm{~K}_{2}\left(137 \mathrm{~kg} \mathrm{ha}^{-1}\right)$ & $988 \mathrm{ab}$ \\
$\mathrm{K}_{3}\left(196 \mathrm{~kg} \mathrm{ha}^{-1}\right)$ & $965 \mathrm{ab}$ \\
$\mathrm{K}_{4}\left(225 \mathrm{~kg} \mathrm{ha}^{-1}\right)$ & $920 \mathrm{a}$ \\
\hline
\end{tabular}

Keterangan: Angka-angka yang diikuti huruf yang sama tidak berbeda nyata pada BNJ $5 \%$

\section{Kadar Serat}

Kadar serat menunjukkan adanya pengaruh dari pemberian dosis pupuk $\mathrm{KCl}$ namun tidak berdampak pada macam varietas ubi jalar. Serat adalah bagian dari bahan nabati dalam ransum yang tahan terhadap pencernaan enzimatik yang tersusun dari polisakarida, oligosakarida, dan lignin (Dhingra et al., 2012). Serat sebagian penyusunannya adalah dari unsur kalium. Stone et al. (2016) menjelaskan bahwa serat pangan dapat berbentuk potasium bikarbonat. Hal tersebut diperkuat dengan adanya penambahan pupuk $\mathrm{KCl}$ dapat meningkatkan kadar serat yang ada pada umbi (Tabel 2).

Tabel 2. Rerata kadar serat dua varietas ubi jalar pada berbagai dosis pemupukan $\mathrm{KCl}$ saat panen

\begin{tabular}{lr}
\hline Dosis Pupuk KCl & Kadar Serat \\
\hline $\mathrm{K}_{0}\left(0 \mathrm{~kg} \mathrm{ha}^{-1}\right)$ & 1,68 a \\
$\mathrm{K}_{1}\left(78 \mathrm{~kg} \mathrm{ha}^{-1}\right)$ & $1,95 \mathrm{a}$ \\
$\mathrm{K}_{2}\left(137 \mathrm{~kg} \mathrm{ha}^{-1}\right)$ & $2,11 \mathrm{a}$ \\
$\mathrm{K}_{3}\left(196 \mathrm{~kg} \mathrm{ha}^{-1}\right)$ & $2,21 \mathrm{a}$ \\
$\mathrm{K}_{4}\left(225 \mathrm{~kg} \mathrm{ha}^{-1}\right)$ & $2,62 \mathrm{~b}$ \\
\hline
\end{tabular}

Keterangan: Angka-angka yang diikuti huruf yang sama tidak berbeda nyata pada BNJ taraf $5 \%$

Pemberian dosis $\mathrm{KCl}$ tertinggi yaitu $130 \%$ menghasilkan kadar serat yang nyata lebih tinggi dibandingkan perlakuan lainnya. Tingginya kadar serat umbi tersebut berkaitan dengan tingginya jumlah pupuk $\mathrm{KCl}$ yang diterima pada perlakuan tersebut. Diketahui bahwa jumlah pupuk yang diberikan pada setiap luasan tidak sama, sedang jumlah populasi per satuan luas lahan adalah sama maka untuk luasan dengan tingkat pemberian $\mathrm{KCl}$ yang tinggi adalah yang paling banyak jumlah unsur $\mathrm{K}$ nya. Peran K lainnya dalam pembentukan dinding sel, dan diketahui bahwa dinding sel tersusun dari selulosa, pectin, dan hemiselulosa yang bersifat kaku dan berserat (Broxterman \& Schols, 2018). Oleh karenanya semakin rendahnya unsur $\mathrm{K}$ yang tersedia bagi tanaman, semakin rendah pula tingkat serapan $\mathrm{K}$ oleh tanaman menyebabkan kadar serat yang terbentuk 
juga rendah (Tabel 2). Hasil analisa regresi memperlihatkan terbentuknya hubungan linier antara kepadatan tanaman $(\mathrm{X})$ dengan kadar serat umbi (Y) yang diberikan dengan persamaan $\mathrm{Y}=0,0036+1,654 \mathrm{R} 2=0,8981$ pada Gambar 1.

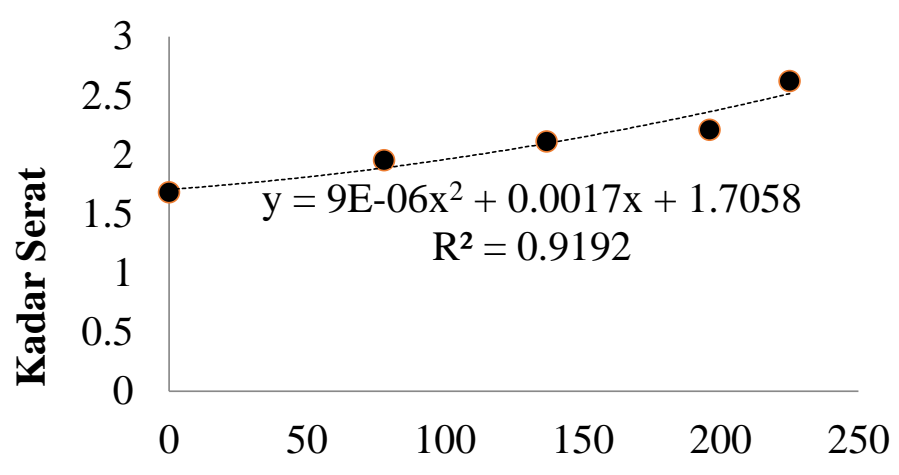

\section{Dosis $\mathrm{KCl}\left(\mathrm{Kg} \mathrm{ha}^{-1}\right)$}

Gambar 1. Bentuk dan pola hubungan antara tingkat pemberian $\mathrm{KCl}$ dengan kadar serat umbi

Adanya persamaan $\mathrm{Y}=0,0036+1,654$ $\mathrm{R} 2=0,8981$ diketahui terdapat hubungan yang mengindikasikan bahwa $89 \%$ kadar serat yang dihasilkan umbi pada kedua varietas dipengaruhi oleh pemberian pupuk $\mathrm{KCl}$ dimana semakin tinggi pemberian pupuk $\mathrm{KCl}$, semakin tinggi kadar serat yang dihasilkan. Pemberian $\mathrm{KCl}$ tidak menunjukkan adanya pengaruh nyata pada kadar gula yang dihasilkan, namun terdapat perbedaan yang signifikan untuk kadar gula yang dimiliki antar varietas. Varietas Cilembu memiliki kadar gula yang tinggi jika dibandingkan dengan varietas Gunung Kawi (Tabel 3). Perbedaan ini tentunya disebabkan fenotip dan genotip dari kedua varietas yang berbeda. Bentuk dan gen pada tanaman akan membantu tanaman dalam memanfaatkan lingkungan dalam pertumbuhannya. Hal ini terlihat jelas dari morfologi kedua varietas yang sangat berbeda.

\section{Kadar Gula}

Tabel 3. Rerata kadar gula dua varietas ubi jalar pada berbagai dosis pemupukan $\mathrm{KCl}$ saat panen

\begin{tabular}{lc}
\hline Macam Varietas & Kadar Gula (\%) \\
\hline Gunung Kawi & $2,61 \mathrm{a}$ \\
Cilembu & $9,63 \mathrm{~b}$ \\
\hline
\end{tabular}

Keterangan: Angka-angka yang diikuti huruf yang sama tidak berbeda nyata pada BNJ taraf $5 \%$

Zaidiyah (2014) menjelaskan bahwa tingkatan glukosa, fruktosa, dan sukrosa setiap varietas berbeda dan dipengaruhi oleh genotip masing-masing varietas. Varietas setiap ubi jalar memiliki karakteristik saat proses penyimpanan ubi berlangsung yang akan berdampak pada akumulasi gula. Pada saat proses pemanisan berlangsung saat masa penyimpanan ubi, penurunan pati terjadi melalui fosforilase pati dan akhirnya secara langsung mengurangi akumulasi gula sebagai dampak dari reaksi enzim. Setiap varietas ubi jalar memiliki jalur organ degradasi pati yang berbeda begitu juga dengan komposisi serta kandungan kimia didalamnya (Franco, 2016). 
Dalam endosperma serealia, degradasi pati terjadi di jaringan tak hidup. Setiap varietas yang ditanam memiliki karakteristik daun yang berbeda. Perbedaan morfologi tersebut akan tampak jelas jika ditanam pada lingkungan yang sama.

Varietas Gunung Kawi memiliki morfologi daun yang bulat dengan tingkat kerapatan daun yang rendah dibandingkan Cilembu sehingga intersepsi radiasi yang diterima akan lebih banyak, menyebabkan laju asimilasi berjalan baik yang berdampak pada berat kering dan hasil panen yang tinggi pula. Berbeda dengan varietas Cilembu yang memiliki ciri daun menjari dengan luas daun lebih sempit serta memiliki tingkat kerapatan daun yang tinggi. Hal tersebut mengacu pada penelitian (Zhang et al., 2018), yang menyatakan bahwa adanya peningkatan intersepsi cahaya didasari pada optimalisasi luas daun yang diikuti peningkatan fotosintesis dan biomassa yang dihasilkan. Jumlah kadar gula yang dihasilkan ditentukan oleh perbedaan genotip juga dibenarkan melalui penelitian George et al. (2015), yang menunjukkan bahwa kandungan gula untuk setiap varietas kentang tidaklah sama.

\section{SIMPULAN}

Pemberian pupuk kalium dapat memengaruhi kualitas dari tanaman ubi jalar kedua varietas. Pemberian kalium $225 \mathrm{~kg}$ $\mathrm{ha}^{-1}$ mampu meningkatkan kadar serat umbi sebesar $35 \%$ namun berdampak pada pengurangan kandungan klorofil sebesar 14\%. Nilai kadar gula ubi jalar, lebih dipengaruhi oleh adanya perbedaan genotip dan fenotip kedua varietas.

\section{DAFTAR PUSTAKA}

Anggraini, Y. D., \& Sri, L. P. (2019). Interaksi Genotip $\mathrm{x}$ Lingkungan Beberapa Genotip Cabai Rawit (Capsicum frutescens L.) di Dua Lokasi. J. Produksi Tanaman, 7(8), 1574-1580.

http://protan.studentjournal.ub.ac.id/ind ex.php/protan/article/view/1212
Bolan, N. S., L., P., \& Surinder, S. (2005). Encyclopedia of Soils in the Environment (pp. 149-154).

Broxterman, S. E., \& Schols, H. A. (2018). Interactions between pectin and cellulose in primary plant cell walls. Carbohydrate Polymers, 192, 263-272. https://doi.org/10.1016/j.carbpol.2018. 03.070

Dhingra, D., Michael, M., Rajput, H., \& Patil, R. T. (2012). Dietary fibre in foods: a review. Journal of Food Science and Technology, 49(3), 255266. https://doi.org/10.1007/s13197011-0365-5

Ding, Y. C., Chang, C.-R., Lou, W., Wu, Y.-S., Ren, X.-L., Wang, P., \& Xu, G.H. (2008). High Potassium Aggravates the Oxidative Stress Inducedy by Magnesium Deflciency in Rice Leaves. Pedosphere, 18(3), 316-327. https://doi.org/10.1016/S10020160(08)60021-1

Ding, Y., Luo, W., \& Xu, G. (2006). Characterisation of magnesium nutrition and interaction of magnesium and potassium in rice. Annals of Applied Biology, 149(2), 111-123. https://doi.org/10.1111/j.17447348.2006.00080.x

Franco, A. (2016). Characterization of Sweet Potato (Ipomoea batatas L.) Starch From Two Clones and Evaluation of Its Properties For Industrial Uses. Conference: AIChe Annual Meeting.

George, J., Kalidas, P., Arup, K. M., \& Archana, M. (2015). High Starch, Low Sugar Yielding Genotypes of Sweet Potato and their Micropropagation. IJTA, 33, 401-404. https://www.cabdirect.org/cabdirect/ab stract/20153325945

Julio Suhardi, C., Ratnawati, R., \& Khotimah, H. (2016). Pengaruh Pemberian Antosianin dari Ipomoea batatas L.Varietas Ungu Kultivar Gunung Kawi dalam Meningkatkan 
Kadar Superoxide Dismutase pada Tikus (Rattus norvegicus) dengan Diet Aterogenik. Majalah Kesehatan, 3(4), 166-173.

https://doi.org/10.21776/ub.majalahkes ehatan.003.04.1

Jusuf, M., \& Ginting, E. (2014). The Prospects and Challenges of Sweet Potato as Bio-ethanol Source in Indonesia. Energy Procedia, 47, 173179.

https://doi.org/10.1016/j.egypro.2014.0 1.211

Pushpalatha, M., Vaidya, P. H., \& Adsul, P. B. (2017). Effect of Graded Levels of Nitrogen and Potassium on Yield and Quality of Sweet Potato (Ipomoea batatas L.). International Journal of Current Microbiology and Applied Sciences, 6(5), 1689-1696. https://doi.org/10.20546/ijcmas.2017.6 05.183

Saitama, A., Nugroho, A., \& Widaryanto, E. (2017). Yield response of ten varieties of sweet potato (Ipomoea batatas L.) cultivated on dryland in rainy season. Journal of Degraded and Mining Lands Management, 04(04), 919-926. https://doi.org/10.15243/jdmlm.2017.0 44.919

Simo, C., Nono, G. V., \& Taffouo, V. D. (2017). Evaluation of different sweet potato varieties for growth, quality and yield traits under chemical fertilizer and organic amendments in sandy ferralitic soils. African Journal of Agricultural Research, 12(48), 33793388.

https://doi.org/10.5897/AJAR2017.126 75

Stone, M., Martyn, L., \& Weaver, C. (2016). Potassium Intake, Bioavailability, Hypertension, and Glucose Control. Nutrients, $\quad 8(7), \quad 444$. https://doi.org/10.3390/nu8070444

Subaedah, S., Aladin, A., \& Nirwana. (2016). Fertilization of nitrogen, phosphor and application of green manure of Crotalaria juncea in increasing yield of maize in marginal dry land. Agriculture and Agricultural Science Procedia, 9, 20-15.

Trustinah, \& Iswanto, R. (2013). Pengelompokan Aksesi Kacang Hijau Berdasarkan Karakter Kuantitatif. Prosiding Seminar Nasional Hasil Penelitian Tanaman Aneka Kacang Dan Umbi, 7-14.

Zaidiyah. (2014). Sucrose, Reducing Sugars, and Carotenoid Content of Aceh Besar Sweet Potato Cultivars (Ipomoea batatas L.). J. Teknologi Dan Industri Pertanian Indonesia, 6(1), 13-16. https://doi.org/https:doi: https://doi.org/10.17969/jtipi.v6i1.1984

Zhang, W., Chen, X.-X., Liu, Y.-M., Liu, D.-Y., Du, Y.-F., Chen, X.-P., \& Zou, C.-Q. (2018). The role of phosphorus supply in maximizing the leaf area, photosynthetic rate, coordinated to grain yield of summer maize. Field Crops Research, 219, 113-119. https://doi.org/10.1016/j.fcr.2018.01.03 1 